\title{
Pengembangan Bahan Ajar berupa E-Book pada Mata Pelajaran Akuntansi Keuangan Kompetensi Dasar Akuntansi Piutang Kelas XI Berbasis Pendekatan Saintifik di SMK Yapalis Krian
}

\author{
Sylvia Maulidah Rahmah \\ e-mail: sylvia.17080304088@mhs.unesa.ac.id \\ Joni Susilowibowo \\ e-mail: jonisusilowibowo@unesa.ac.id
}

(Program Studi Pendidikan Akuntansi, Fakultas Ekonomika dan Bisnis, Universitas Negeri Surabaya)

\begin{abstract}
ABSTRAK : Penelitian ini bertujuan untuk mengembangkan bahan ajar e-book, menganalisis tingkat kelayakan e-book dan menganalisis respon peserta didik terhadap e-book. Mata pelajaran dalam penelitian ini adalah akuntansi keuangan pada kompetensi dasar akuntansi piutang. Bahan ajar berupa e-book dikembangkan sesuai implementasi kurikulum 2013 berbasis pendeketan saintifik. Metode penelitian yang digunakan adalah Research and Development (RED) dengan model 4-D. Validator dalam penelitian adalah 3 dosen sesuai bidang yang dituju serta salah satu guru yang ahli dalam mata pelajaran akuntansi keuangan. Data penilaian yang disebar kepada validator berasal dari lembar telaah lalu lembar validasi. Sejumlah 20 peserta didik kelas XI Akuntansi Keuangan dan Lembaga di SMK Yapalis Krian juga sebagai salah satu responden. Hal tersebut untuk mengetahui kelayakan bahan ajar sehingga cocok dipergunakan dalam proses pembelajaran. Produk yang dikembangkan menghasilkan interpertasi sangat layak dengan rekapitulasi rerata kelayakan 89,49\%. Dari hasil tersebut ada beberapa komponen yang dicantumkan dengan interpertasi sangat layak yaitu kelayakan materi 89,89\%,kelayakan bahasa 86,67\% dan kelayakan grafis 91,93\%. Untuk hasil rerata peserta didik menyatakan interpertasi sangat dipahami dengan persentase sebesar $88,12 \%$. Maka bahan ajar ini cocok digunakan dalam proses pembelajaran.
\end{abstract}

Kata kunci - E-book, Akuntansi Keuangan, Pendekatan Saintifik.

ABSTRACT : This research aims to develop e-book teaching materials, analyze the feasibility level of $e$ books and analyze student responses to e-books. The subjects in this study are financial accounting on the basic competence of accounts receivable accounting. Teaching materials in the form of e-books were developed according to the implementation of the 2013 curriculum based on a scientific approach. The research method used is Research and Development (RED) with a 4-D model. The validators in the study were 3 lecturers according to the intended field and one teacher who was an expert in financial accounting subjects. The assessment data distributed to the validator comes from the review sheet and then the validation sheet. A total of 20 students of class XI Financial and Institutional Accounting at SMK Yapalis Krian were also one of the respondents. This is to determine the feasibility of teaching materials so that they are suitable for use in the learning process. The product developed produces a very feasible interpretation with an average feasibility recapitulation of $89.49 \%$. From these results, there are several components listed with very feasible interpretations, namely the feasibility of the material $89.89 \%$, the feasibility of language $86.67 \%$ and the feasibility of graphics $91.93 \%$. For the average results, students stated that the interpretation was very well understood with a percentage of $88.12 \%$. So this teaching material is suitable for use in the learning process.

Keywords - E-book, Financial Accounting, Scientific Approach. 


\section{PENDAHULUAN}

Pendidikan adalah suatu aktivitas yang dilakukan manusia selama masa hidupnya untuk belajar agar tercipta sumber daya manusia yang berkompeten untuk pembangunan nasional (Kirana, R \& Susilowibowo, 2020). Pada Undang-Undang Republik Indonesia Nomor 20 Tahun 2003 pasal 1 ayat (1) terkait sistem pendidikan nasional, kegiatan pendidikan diselenggarakan dalam jalur pendidikan formal, non-formal maupun informal. Sekolah Menengah Kejuruan (SMK) termasuk salah satu jenjang pendidikan formal. Peserta didik akan memperoleh atau menambah ilmu pengetahuan dan keterampilan dari berbagai jenjang pendidikan yang ditempuh.

Indonesia sekarang mengalami dampak pandemi covid-19 yang mengakibatkan mobilitas pendidikan mengalami perubahan terutama pembelajaran secara langsung yang dialihkan menjadi pembelajaran jarak jauh atau disebut daring. Dari berbagai jenjang pendidikan akan membutuhkan bantuan teknologi informasi agar proses pembelajaran mencapai keberhasilan. Guru sebagai tenaga pendidik yang harus memberikan materi pembelajaran dengan metode yang akan diterapkan agar peserta didik tetap menerima pengetahuan dan keterampilan meskipun menggunakan sistem daring. Saat ini, pendidik dituntut bisa mengoperasikan perangkat lunak atau aplikasi serta meningkatkan kreativitas yang mendukung pembelajaran online (Arianti, 2021). Namun seiring berjalannya waktu, beberapa sekolah tidak hanya melakukan pembelajaran dengan sistem daring tetapi ada pembelajaran tatap muka atau sistem luring.

Setiap sekolah khususnya Sekolah Menengah Kejuruan (SMK) tetap berupaya menerapkan kurikulum 2013 meskipun kegiatan pembelajaran dalam sistem daring maupun luring. Penerapan Kurikulum 2013 dapat menyeimbangkan dan meningkatkan kemampuan peserta didik yaitu softskill dan hardskill yang berupa pengetahuan, keterampilan dan sikap (Fadillah, 2014). Pelaksanaan Kurikulum 2013 akan ditentukan oleh kesiapan guru dalam mengimplementasikan kurikulum saat mengajar (Zaim, 2017). Kurikulum saat ini dalam proses kegiatan pembelajaran memakai pendekatan saintifik yang mempunyai 5 keterampilan biasa disebut $5 \mathrm{M}$ yakni mengamati, menanyakan, mengumpulkan informasi, mengasosiasi dan mengkomunikasikan. Dalam pendekatan saintifik, guru bertugas untuk mendidik siswa menjadi kreatif dan mampu berpikir kritis dalam setiap permasalahan (Ramdhani et al., 2017)

Pendukung proses pembelajaran yang optimal secara daring maupun luring serta mengimplementasikan kurikulum 2013 maka dibutuhkan bahan ajar. Bahan ajar adalah materi yang dikumpulkan dari berbagai sumber (Andi, 2015) dan disusun secara sistematis dengan bahasa yang mudah dimengerti, dilihat dari umur dan tingkatan pengetahuan pembaca agar sanggup belajar secara mandiri (Wahyuni, 2015). Dengan adanya bahan ajar, guru lebih terbantu dalam kegiatan mengajar dan peserta didik dengan mudah mendapatkan pengetahuan dalam proses pembelajaran. Menciptakan inovasi baru pada bahan ajar menumbuhkan minat belajar peserta didik (Putra \& Pamungkas, 2019). Untuk meningkatkan kualitas pembelajaran maka dibutuhkan bahan ajar yang inovatif. Peran bahan ajar inovatif menumbuhkan minat peserta didik lebih mandiri, aktif dan meningkatkan kemampuaan literasi yang dimiliki.

Bahan ajar dapat berupa media cetak maupun non cetak (Saputri \& Susilowibowo, 2020). Seiring berkembangnya ilmu pengetahuan dan teknologi, bahan ajar non cetak atau bentuk digital dalam penggunaannya lebih efisien dan efektif. Contoh dari bahan ajar non cetak adalah e-book, yaitu buku teks yang di produksi dan diterbitkan melalui perangkat digital selain itu bisa menambahkan fitur-fitur seperti video/animasi, gambar maupun suara (Suarez \& Wooudhuyusen, 2013). Keunggulan dalam penggunaan bahan ajar berupa e-book yaitu tidak lapuk, ramah lingkungan, mudah disebarkan, mudah diakses, praktis dan portable (Ruddamayanti, 2019). Menurut Shirratudin (2003) manfaat $e$-book dalam dunia pendidikan dapat meningkatkan interaksi peserta didik dengan guru dalam pembelajaran jarak jauh serta dalam penggunaan e-book saat pembelajaran peserta didik lebih tertarik (dalam Restiyowati \& Sanjaya, 2012). Buku elektronik 
akan dikombinasikan dengan aplikasi atau perangkat lunak lainnya. Penggunaan bahan ajar e-book diharapkan sebagai pendukung proses pembelajaran agar lebih tepat guna.

Berdasarkan wawancara kepada salah satu guru akuntansi yang menempuh mata pelajaran Akuntansi Keuangan kelas XI, Guru memiliki bahan ajar pegangan yaitu buku paket dan LKS. Namun, terjadinya perbedaan urutan materi pada buku paket dan LKS sehingga guru harus menyesuaikan kembali dalam menyampaikan ke peserta didik. Selain itu, peserta didik hanya difasilitasi buku paket dari perpustakaan dan jumlahnya terbatas. Hal tersebut membuat peserta didik ada yang kebagian pinjaman buku dan tidak. Peserta didik yang mendapatkan pinjaman buku tidak sepenuhnya memiliki buku pegangan. Oleh karena itu, bahan ajar yang dibutuhkan guru harus bersifat mudah dipahami, kreatif dan inovatif untuk diberikan kepada peserta didik sebagai tambahan sumber belajar. Selain itu, guru dapat meningkatkan keterampilan di bidang teknologi.

Permasalahan-permasalahan tersebut, perlu dibuat bahan ajar yang sesuai dengan kompetensi dasar dan mudah dipahami oleh peserta didik dalam teori, perhitungan dan penjurnalan. Bahan ajar akan dipublikasikan bertujuan memudahkan peserta didik untuk mendapatkan informasi. Bahan ajar disusun secara komprehensif dan dibuat berbasis teknologi dengan bantuan aplikasi Flipbook Pdf Proffesional. Hal tersebut agar peserta didik dapat mengikuti perkembangan zaman. Pengembangan $e$-book ini diharapkan guru atau pendidik dapat terbantu dalam mengajar pada mata pelajaran akuntansi keuangan khususnya kompetensi dasar akuntansi piutang yang bertujuan peserta didik mudah memahami materi. SMK Yapalis Krian sedang menerapkan pembelajaran daring maupun luring, maka bahan ajar dapat dimanfaatkan untuk peserta didik dalam menguasai materi secara mandiri walaupun dengan pembelajaran jarak jauh. E-book ini dapat dibaca dimana dan kapan saja, bahasa yang digunakan mudah dipahami serta dapat dioperasikan melalui smartphone secara offline tentunya dalam penggunaan tanpa ada keterbatasan waktu untuk belajar. Melalui bahan ajar yang tepat, maka dapat meningkatkan kemandirian peserta didik sehingga akan berdampak pada kemampuan belajar peserta didik (Sari \& Zamroni, 2019).

Berdasarkan penjelasan diatas, tujuan penulisan yang dapat disusun peneliti adalah (1) menganalisis proses pengembangan bahan ajar berupa e-book di SMK Yapalis Krian (2) menganalisis kelayakan bahan ajar berupa e-book di SMK Yapalis Krian (3) menganalisis respon peserta didik terhadap bahan ajar berupa e-book di SMK Yapalis Krian.

\section{METODE}

Penelitian ini digolongkan sebagai penelitian pengembangan atau Research and Development (R\&D). Model pengembangan 4-D pada teori Thiagarajan sebagai acuan dalam penelitian pengembangan bahan ajar berupa e-book yang terdiri 4 tahap pengembangan yaitu define yang diartikan pendefinisian, design atau perancangan, development diartikan pengembangan dan yang terakhir disseminate atau diartikan penyebaran. Tahap pertama define memiliki lima kegiatan yang harus dilakukan yaitu analisis ujung depan, analisis peserta didik, analisis tugas, analisis konsep dan perumusan tujuan pembelajaran. Tahap kedua yaitu design yang memiliki dua tahap diantaranya penyusunan format produk dan desain awal produk. Selanjutnya, development sebagai tahap ketiga yang terdapat dari telaah para ahli, menganalisis hasil telaah dan revisi, validasi para ahli dan menganalisnya serta melakukan uji coba terbatas. Dan peneliti tidak melakukan tahap disseminate karena keterbatasan kemampuan.

Subjek uji coba dalam penelitian ini adalah dosen S1 Pendidikan Akuntansi Unesa dan guru akuntansi yang mampu dalam mata pelajaran akuntansi keuangan sebagai validator materi, dosen Fakultas Bahasa dan Sastra Indonesia Unesa sebagai validator bahasa, dosen Teknologi dan Kurikulum Pendidikan Unesa sebagai validator grafis, serta peserta didik kelas XI AKL di SMK 
Yapalis Krian. Terdapat jenis data kualitatif dan kuantitatif dalam pengembangan ini. Untuk data kualitatif diperoleh dari wawancara dengan guru atau pendidik disekolah yang dipilih dan hasil telaah $e$-book dari beberapa para ahli yang bersangkutan sedangkan hasil validasi dari dosen ahli materi, bahasa dan grafis serta respon peserta didik tentang produk e-book tersebut merupakan data kuantitatif.

Instrumen pengumpulan data sebagai alat bantu dalam penelitian agar lebih mudah dan sistematis (Riduwan, 2016). Salah satu instrumen pengumpulan data yaitu angket. Terdapat dua jenis angket yaitu terbuka dan tertutup. Angket terbuka diberikan kepada para ahli untuk mengisi lembar telaah yang sudah diolah sesuai dengan (BSNP, 2014). Sedangkan untuk angket tertutup ditunjukan kepada para ahli untuk mengisi lembar validasi dengan hasil olahan dari peneliti yang telah disesuaikan dengan (BSNP, 2014). Lembar telaah yang diberikan berisi komentar umum dan saran berguna untuk melakukan perbaikan pada produk yang dikembangkan yaitu bahan ajar $e$ book agar layak dipakai dalam proses pembelajaran. Lembar telaah meliputi aspek isi, penyajian, bahasa dan kegrafisan. Sedangkan, untuk lembar validasi berisi kategori penilaian yang menggunakan skala likert dengan skor terendah 1 sampai skor tertinggi 5, kemudian hasil validasi akan di analisis dengan teknik presentase sesuai tingkat kelayakan. Tahap selanjutnya yaitu respon peserta didik yang akan melakukan uji coba terbatas. Oleh karena itu, sejumlah 20 peserta didik diberikan angket untuk menilai produk tersebut setelah mengoperasikan dan menggunakannya. Angket untuk peserta didik akan dianalisis menggunakan perhitungan skala Guttman.

\section{PEMBAHASAN}

\section{Proses Pengembangan Bahan Ajar E-Book Berbasis Pendekatan Saintifik}

Pengembangan bahan ajar e-book yang berpedoman pada model pengembangan 4-D Thiagarajan. Prosedur penelitian ini akan dilakukan dengan empat tahapan mulai dari Define, Design, Develop, dan Disseminate.

\section{Define}

Pada proses Define yang menjadi tahap pertama mengetahui permasalahan dasar yang sedang dihadapi pada proses pembelajaran sehingga dibutuhkan pengembangan bahan ajar. Bahan ajar yang digunakan guru berupa buku paket dan LKS memiliki perbedaan urutan materi sehingga guru harus menyesuaikannya kembali. Hal tersebut dikatakan bahan ajar belum sesuai dengan kompetensi dasar. Guru juga berpendapat bahwa kompetensi dasar akuntansi piutang memerlukan pemahaman yang lebih dalam. Lalu pendidik dalam penyampaian materi masih menggunakan metode tradisional yang mengakibatkan proses pembelajaran peserta didik cenderung lebih pasif. Maka peserta didik memerlukan bahan ajar tambahan agar menarik perhatiannya dengan menyajikan materi yang mudah dipahami dan jelas. Peneliti mengembangkan bahan ajar e-book, diharapkan peserta didik mampu memenuhi tujuan pembelajaran yang ada serta dapat menerapkan kurikulum 2013 yang didalamnya terdapat model pembelajaran pendekatan saintifik yang menuntut peserta didik agar aktif dalam pembelajaran dikelas (student center). Agar peserta didik lebih menguasai penerapan akuntansi piutang di setiap bab disajikan soal pilihan ganda dan uraian. Peneliti menyesuaikan kompetensi dasar yang tercantum di silabus pada mata pelajaran akuntansi keuangan kelas XI khususnya materi akuntansi piutang yang berisi KD 3.2 sampai KD 3.4.

\section{Design}

Tahap kedua yaitu Design yang bertujuan untuk menyiapkan perangkat pembelajaran (Sumiadi, 2015). Tahap ini diawali dengan menentukan format awal yang akan digunakan bahan ajar e-book. Format awal e-book yang memiliki 3 bagian yaitu pendahuluan, isi dan penutup. Format 
bahan ajar e-book ini berpatokan pada struktur BSNP (2014) yang telah dimodifikasi peneliti. Setelah penyusunan format $e$-book, dilakukan penggabungan rancangan awal $e$-book menjadi satu kesatuan hingga memperoleh draft pertama. Pengembangan bahan ajar e-book ini dapat diakses melalui handphone secara offline dengan mengunduh link yang disediakan.

Fitur - fitur dalam e-book ini menerapkan pembelajaran 5M yaitu dari tahap mengamati dengan menampilkan sebuah video berisi gambaran materi yang akan disampaikan dan terdapat QR Code untuk mengakses videonya jika peserta didik tidak mengunduh aplikasi hanya mempunyai file $P d f$ e-book akuntansi keuangan ini, selanjutnya tahap menanya berisi pertanyaan tentang pemahaman peserta didik terhadap video yang sudah ditampilkan jadi tugas guru menjawab pertanyaan yang ditanyakan oleh peserta didik, tahap mengumpulkan informasi berisi materi lengkap yang sesuai dengan indikator pencapaian kompetensi, tahap mengasosiasi berisi soal diskusi untuk meningkatkan penalaran pesesrta didik, selain itu terdapat refleksi diri berisi ceklist untuk mengukur pemahaman peserta didik terhadap materi, dan tahap terakhir yaitu mengkomunikasikan berisi peserta didik diperintah untuk mempresentasikan hasil diskusinya. $E$ book ini juga terdapat latihan soal yang harus dikerjakan peserta didik untuk mengetahui pemahaman terhadap materi yang dipelajari. Latihan soal tersebut berisi soal berbasis HOTS pilihan ganda dan uraian. Bagian akhir e-book terdapat glosarium yang berisi definis, arti,dan uraian istilah-istilah penting.

\section{Develop}

Tahap ketiga yaitu Develop, pada tahapan ini terdiri dari telaah para ahli dari materi, bahasa dan grafis. Tujuan tahap Develop adalah menghasilkan perangkat pembelajaran yang telah direvisi berdasarkan masukan dari penelaah atau validator (Hikmawati et al., 2019). Telaah yaitu proses mengkaji berupa saran, nasihat dan kritikan terhadap produk pada penelitian pengembangan yang dilakukan oleh para ahli. Telaah ahli materi memberikan saran materi yang dicantumkan sesuai dengan Pernyataan Standar Akuntansi (PSAK), menambah beberapa soal pilihan ganda dan merapikan susunan tabel. Telaah ahli bahasa menyarankan untuk memperbaiki beberapa kata yang tidak sesuai dengan KBBI dan PUEBI sehingga menjadi produk yang baik dan telaah ahli grafis memberikan saran untuk memperbaiki pengetikan halaman yang melebihi batas margin serta pada cover belakang ditambahkan keterangan tentang isi $e$-book. Setelah melakukan telaah kemudian memperbaiki draft 1 maka akan menghasilkan draft 2. Kemudian, draft 2 dilanjutkan untuk tahap validasi oleh para ahli dengan memberikan skor 1 sampai 5 dan hasilnya diinterpertasikan untuk menghasilkan nilai kelayakan pada e-book akuntansi keuangan kompetensi dasar akuntansi piutang.

\section{Kelayakan Bahan Ajar E-Book Berbasis Pendekatan Saintifik}

Hasil analisis dari berbagai validator menentukan kelayakan pada bahan ajar e-book. Validator memberi skor produk yang dikembangkan peneliti diperoleh dari validator materi, validator bahasa dan validator grafis. Skor ini didapatkan dari lembar validasi tersebut yang akan dijumlahkan dan dianalisis menggunakan metode presentase yang kemudian diinterpertasikan. Berikut penyajian hasil validator materi yaitu: 
Tabel 5. Hasil Validasi Kelayakan Materi

\begin{tabular}{llllll}
\hline No & Aspek & Ahli 1 & Ahli 2 & Presentase & Interpertasi \\
\hline $\mathbf{1}$ & Cakupan Materi & $100 \%$ & $100 \%$ & $100 \%$ & Sangat Layak \\
$\mathbf{2}$ & Akurasi Materi & $80 \%$ & $86,67 \%$ & $83,33 \%$ & Sangat Layak \\
$\mathbf{3}$ & Kemutakhiran dan Konstektual & $80 \%$ & $86,67 \%$ & $83,33 \%$ & Sangat Layak \\
$\mathbf{4}$ & Ketaatan Hukum dan Perundang- & $100 \%$ & $100 \%$ & $100 \%$ & Sangat Layak \\
& Undangan & & & & \\
$\mathbf{5}$ & Teknik Penyajian & $85 \%$ & $85 \%$ & $85 \%$ & Sangat Layak \\
$\mathbf{6}$ & Pendukung Penyajian Materi & $82,5 \%$ & $92,5 \%$ & $87,5 \%$ & Sangat Layak \\
$\mathbf{7}$ & Penyajian Pembelajaran & $86,67 \%$ & $93,33 \%$ & $90 \%$ & Sangat Layak \\
$\mathbf{8}$ & Kelengkapan Penyajian & $85 \%$ & $95 \%$ & $90 \%$ & Sangat Layak \\
\hline Rerata Kelayakan Materi & $87,39 \%$ & $92,39 \%$ & $89,89 \%$ & Sangat Layak \\
\hline
\end{tabular}

Sumber: Diolah oleh peneliti (2021)

Data yang diperoleh, penyajian bahan ajar yang divalidasi oleh ahli materi 1 yakni Drs.Joni Susilowibowo, M.Pd selaku dosen S1 Pendidikan Akuntansi Unesa dengan hasil presentase kelayakan materi sebesar 87,39\% mendapatkan interpertasi sangat layak dan dari ahli materi 2 yakni Mirzadia Ariyanti, S.E selaku guru pengampu mata pelajaran akuntansi keuangan yang memberikan hasil presentase sebesar $92,39 \%$ dengan interpertasi sangat layak maka rerata kelayakan dari ahli materi 1 dan 2 sebesar 89,89\% dengan interpertasi sangat layak. Kesimpulan yang diperoleh dari hasil validator yaitu dalam cakupan materi sudah sesuai dengan kompetensi dasar yang beracuan dengan silabus. Pada penyajian materi aspek keterampilan dengan karakteristik 5M dan setiap bab disajikan peta konsep serta contoh soal yang konkrit. Selain itu $e-$ book menyajikan soal diskusi, pilihan ganda serta uraian yang dapat dikerjakan peserta didik untuk mengetahui kemampuan setiap individu. Dalam kelengkapan penyajian, sudah mencantumkan aspek pendahuluan seperti cara penggunaan e-book, daftar isi, glosarium dan daftar pustaka.

Hasil validasi tersebut selaras dengan penelitian yang dilakukan Nurfita \& Susanti, (2018) bahwa bahan ajar akuntansi keuangan yang dikembangkan pada kelayakan isi memperoleh persentase $80,61 \%$ serta kelayakan penyajian memperoleh persentase $81,25 \%$ sehingga pada aspek materi memperoleh rerata kelayakan 80,93\% termasuk kriteria layak. Penelitian lain juga dilakukan Kirana \& Susilowibowo, (2020) yang mengembangkan bahan ajar berupa e-book memperoleh rerata kelayakan isi $86,9 \%$ dan kelayakan penyajian $85 \%$ sehingga pada aspek materi memperolah rerata kelayakan $85,9 \%$ maka dikatakan sangat layak.

Tabel 6. Hasil Validasi Kelayakan Bahasa

\begin{tabular}{|c|c|c|c|}
\hline No & Aspek & Presentase & Interpertasi \\
\hline 1 & $\begin{array}{l}\text { Kesesuaian dengan Tingkat perkembangan } \\
\text { Peserta Didik }\end{array}$ & $90 \%$ & Sangat Layak \\
\hline 2 & Keterbacaan & $80 \%$ & Layak \\
\hline 3 & Kemampuan Memotivasi & $80 \%$ & Layak \\
\hline 4 & Kelugasan & $90 \%$ & Sangat Layak \\
\hline 5 & Koherensi dan Keruntutan Alur Berpikir & $100 \%$ & Sangat Layak \\
\hline 6 & Kesesuaian dengan Kaidah Bahasa & $80 \%$ & Layak \\
\hline 7 & $\begin{array}{l}\text { Indonesia } \\
\text { Teknik Penyajian }\end{array}$ & $86,67 \%$ & Sangat Layak \\
\hline & Rerata Kelayakan Bahasa & $86,67 \%$ & Sangat Layak \\
\hline
\end{tabular}

Sumber: Diolah oleh peneliti (2021) 
Kajian serta validasi yang diperoleh, dari dosen Fakultas Bahasa yakni Hespi Septiani, S.pd, M.Pd. Pada tabel hasil validator ahli bahasa, diketahui aspek kelayakan bahasa mendapatkan persentase rerata kelayakan sebesar $86,7 \%$ dengan interpertasi sangat layak. Hasil tersebut diperoleh karena penggunaan bahasa yang efisien untuk tingkat perkembangan peserta didik. Tingkat keterbacaan dan ketepatan struktur kalimat terhadap penyajian pesan dan materi dalam $e$ book mudah dipahami peserta didik. Kemampuan memberikan motivasi cukup baik dengan tujuan peserta didik berminat untuk meningkatkan literasi dan belajar mandiri. Kaidah bahasa Indonesia yang tercantum pada bahan ajar sesuai dengan KBBI dan PUEBI serta dalam teknik penyajian sudah cukup konsisten dalam penggunaan istilah, simbol/lambang dan nama asing.

Hasil validasi ini selaras dengan penelitian yang dilakukan Tania, (2017) bahwa penggunaan bahasa sesuai dengan tingkat perkembangan peserta didik sehingga memperoleh hasil rerata kelayakan bahasa sebesar 80\%. Penelitian lain juga dilakukan oleh Wahyuni, (2015) yang mengembangkan bahan ajar elektronik memperoleh hasil validasi dari dua ahli praktisi dan dua ahli materi yang menunjukkan rerata kelayakan bahasa $82,75 \%$ dengan interpertasi sangat baik.

Tabel 7. Hasil Validasi Kelayakan Grafis

\begin{tabular}{llll}
\hline No & Aspek & Presentase & Interpertasi \\
\hline $\mathbf{1}$ & Ukuran Bahan Ajar E-book & $100 \%$ & Sangat Layak \\
$\mathbf{2}$ & Tata Letak Cover Bahan Ajar E-book & $82,85 \%$ & Sangat Layak \\
$\mathbf{3}$ & Tipografi Cover bahan Ajar E-book & $100 \%$ & Sangat Layak \\
$\mathbf{4}$ & Ilustrasi Cover Bahan Ajar E-book & $86,67 \%$ & Sangat Layak \\
$\mathbf{5}$ & Tata Letak Isi E-book & $86 \%$ & Sangat Layak \\
$\mathbf{6}$ & Tipografi Isi Bahan ajar E-book & $98 \%$ & Sangat Layak \\
$\mathbf{7}$ & Ilustrasi bahan Ajar E-book & $90 \%$ & Sangat Layak \\
\hline & Rerata Kelayakan Grafis & $91,93 \%$ & Sangat Layak \\
\hline
\end{tabular}

Sumber: Diolah oleh peneliti (2021)

Validasi dari ahli grafis memperoleh rerata kelayakan sebesar 91,93\% dengan interpertasi sangat layak. Hasil kelayakan grafis diperoleh dari penilaian dosen Fakultas Ilmu Pendidikan yakni Khusnul Khotimah, S.Pd, M.Pd. Perolehan didasari dengan alasan ukuran/format bahan ajar sudah sesuai dengan standar ISO. Pada penataan desain cover bahan ajar cukup baik yang meliputi ukuran dan kombinasi jenis huruf yang proposional, warna yang kontras dan penggunaan ilustrasi yang menggambarkan isi materi. Untuk desain bagian isi $e$-book, penyusunan tata letak sudah cukup konsisten bisa dilihat dari pengaturan margin, paragraf, gambar, tabel dan angka halaman. Pengunaan $e-b o o k$ bisa diakses melalui smartphone yang dapat memudahkan peserta didik untuk mengoperasikannya.

Hasil validasi tersebut selaras dengan penelitian yang dilakukan Pratiwi, (2019) bahwa bahan ajar e-book yang dikembangkan memperoleh rerata kelayakan grafis $84,34 \%$ dalam interpertasi sangat layak untuk dipakai bahan ajar yang disusun sesuai standar BSNP yang mencakup desain cover dan isi e-book. Penelitian lain juga dilakukan Nurfita \& Susanti, (2018) dalam pengembangan bahan ajar akuntansi keuangan yang menyatakan interpertasi sangat layak dengan rerata kelayakan kegrafikan 98,82\% dilihat dari ukuran bahan ajar e-book, desain cover dan desain isi $e$-book yang sesuai. 
Tabel 8. Rekapitulasi Hasil Validasi Ahli

\begin{tabular}{llll}
\hline No & Aspek & Presentase & Interpertasi \\
\hline $\mathbf{1}$ & Materi & $89,89 \%$ & Sangat Layak \\
$\mathbf{2}$ & Bahasa & $86,67 \%$ & Sangat Layak \\
$\mathbf{3}$ & Grafis & $91,93 \%$ & Sangat Layak \\
\hline \multicolumn{2}{l}{ Rerata Kelayakan Bahan Ajar E-book } & $89,49 \%$ & Sangat Layak \\
\hline
\end{tabular}

Sumber: Diolah oleh peneliti (2021)

Mengacu pada perhitungan hasil validasi ketiga tabel memperoleh interpertasi sangat layak dari penilaian validator materi, bahasa dan grafis dengan rerata kelayakan 89,49\% yang mencakup beberapa komponen. Kesimpulan dari hasil tersebut bahan ajar yang dikembangkan berupa $e$-book berbasis pendekatan saintifik dalam penyajian materi sudah sesuai. Bahasa pada $e-$ book yang dibuat mudah dipahami peserta didik dan sesuai dengan kaidah bahasa Indonesia. Aspek grafis meliputi ukuran, desain cover dan isi e-book yang sudah sesuai menurut pedoman BSNP (2014). E-book dapat dimanfaatkan sebagai penunjang proses pembelajaran sesuai dengan perkembangan IPTEK dan siap untuk diuji coba dengan menyebarkan bahan ajar kepada peserta didik.

Hasil rekapitulasi yang telah dianalisis oleh peneliti sejalan dengan Setiyoningrum \& Susilowibowo, (2019) mengembangkan buku ajar berbasis saintifik yang menunjukkan rerata presentase sebesar $88,38 \%$ dalam interpertasi sangat layak dilihat dari isi materi, penyajian materi, kegrafisan dan kebahasaan. Penelitian lain juga dilakukan oleh Fitriani, (2019) dalam pengembangan $e$-book dengan pendekatan saintifik yang mendapatkan hasil dari ketiga komponen (materi, bahasa dan grafis) dengan rerata presentase $84,71 \%$ menunjukkan interpertasi sangat layak.

Analisis terhadap kelayakan bahan ajar ini dapat menjadi pertimbangan kompetensi guru pengajar. Kompetensi tersebut memiliki lima aspek yang saling berkaitan, a.ntara lain (1) konsep yang diajarkan dengan kehidupan nyata lingkungan, (2) menyampaikan materi yang mudah dipahami oleh siswa, (3) menerapkan metode ilmiah sesuai materi pelajaran, (4) menyampaikan materi secara menarik dan tepat, dan (5) melakukan penilaian autentik dan pemilihan bahasa yang mudah dipahami (Suarman et al., 2018). Selain itu, kelayakan bahan ajar pada e-book ini memberikan pelatihan untuk mengajarkan keterampilan berpikir kritis kepada calon guru. Guru harus mengajarkan keterampilan kognitif kepada calon guru sebelum mereka melatihnya kepada peserta didiknya di dalam kelas. Ketika guru dan calon guru dilatih dan mampu berpikir kritis, mereka akan dapat meningkatkan kemampuan menganalisis siswa (Prayogi et al., 2018).

\section{Respon Peserta Didik terhadap Bahan Ajar E-Book Berbasis Pendekatan Saintifik}

Peneliti melakukan uji coba terbatas sejumlah 20 peserta didik kelas XI Akuntansi dan Keuangan Lembaga di SMK Yapalis Krian untuk mendapatkan hasil analisis respon peserta didik. Tahap uji coba dimulai menyebarkan ke peserta didik sebuah link untuk mendownload e-book dan angket yang berisi pernyataan tentang isi, penyajian, bahasa dan grafis pada bahan ajar $e$-book.

Tabel 9. Hasil Analisis Respon Peserta Didik

\begin{tabular}{llll}
\hline No & Aspek & Presentase & Interpertasi \\
\hline $\mathbf{1}$ & Isi & $85 \%$ & Sangat Dipahami \\
$\mathbf{2}$ & Penyajian & $86,25 \%$ & Sangat Dipahami \\
$\mathbf{3}$ & Bahasa & $95 \%$ & Sangat Dipahami \\
$\mathbf{4}$ & Grafis & $86,25 \%$ & Sangat Dipahami \\
\hline Rerata Presentase Penilaian Kategori & $88,12 \%$ & Sangat Dipahami \\
\hline
\end{tabular}

Sumber: Diolah oleh peneliti (2021) 
Berdasarkan hasil analisis respon peserta didik terhadap pengembangan bahan ajar berupa e-book pada aspek isi memperoleh presentase sebesar $85 \%$. Hal ini membuktikan bahwa penyajian isi materi pada bahan ajar berupa e-book dapat mempermudah pemahaman materi dan meningkatkan motivasi untuk mempelajari materi. Pada aspek penyajian memperoleh presentase 86,25\% yang membuktikan bahwa petunjuk penggunaan e-book, peta konsep, materi serta latihan soal sudah sesuai dengan mata pelajaran akuntansi keuangan khususnya akuntansi piutang. Aspek bahasa mendapatkan hasil presentase 95\%. Hal ini membuktikan bahwa ketepatan bahasa yang digunakan sudah benar dan sesuai dengan pola berpikir peserta didik sehingga memudahkan dalam memahami isi dari e-book tersebut. Aspek grafis mendapatkan hasil presentase $86,25 \%$ maka hasil tersebut terbukti bahwa desain e-book yang menarik sehingga mendorong minat baca peserta didik. Pemahaman peserta didik dalam setiap penyampaian materi menjadi prioritas utama agar tidak terjadi kesalahpahaman dalam menyelesaikan suatu permasalahan. Melalui penyampaian isi, penyajian, bahasa, dan grafis, pemikiran peserta didik dapat berkembang sesuai dengan materi dan soal-soal yang diberikan. Hal ini bertujuan agar peserta didik dapat berpikir kritis karena karena kegiatan menganalisis, mengevaluasi, dan mengolah persoalan menjadi sebuah penyelesaian sesuai dengan aktivitas kognitif (Dwi Saputra et al., 2018).

Berdasarkan hasil data diatas rerata presentase penilaian yang didapat dari penyebaran angket peserta didik yaitu $88,12 \%$. Dalam (Riduwan, 2016) dikatakan interpertasi sangat dipahami dengan presentase $\geq 81 \%$ sehingga bahan ajar e-book ini dinyatakan sangat dipahami. Bahan ajar yang dikembangkan oleh peneliti merupakan salah satu alternatif dalam proses pembelajaran dan dapat digunakan sebagai sumber belajar. Dapat disimpulkan dalam menyajikan materi dan penggunaan bahasa mudah dipahami, tampilan yang menarik dari segi cover dan isi serta dapat memotivasi minat baca peserta didik. Hasil respon siswa selaras dengan penelitian yang dilakukan Efendhi \& Susilowibowo, (2013) bahwa bahan ajar berbasis pendekatan saintifik yang mempunyai empat aspek dimulai dari isi, penyajian, bahasa dan grafis memperoleh rerata persentase sebesar 97,50\% dalam interpertasi sangat dipahami sehingga bahan ajar tersebut layak digunakan dalam kegiatan pembelajaran. Penelitian lain juga dilakukan oleh Astuti \& Rahmawati, (2017) yang mengembangkan bahan ajar akuntansi memperoleh hasil penilaian respon peserta didik dengan interpertasi sangat layak.

\section{KESIMPULAN}

Bersumber pada hasil penelitian, dapat disimpulkan dari pengembangan produk yang menghasilkan bahan ajar berupa e-book mata pelajaran akuntansi keuangan kompetensi dasar akuntansi piutang dengan pendekatan saintifik yang menggunakan model pengembangan 4-D (define, design, develop, dan disseminate). Akan tetapi, tidak dilakukan tahap terakhir karena keterbatasan kemampuan peneliti dalam melakukan disseminate. E-book ini dapat diakses memalui smartphone dengan mendownload melalui link yang disebar peneliti sehingga dapat mempermudah peserta didik untuk belajar. Penilaian dari hasil validasi dibidang materi, bahasa dan grafis menunjukkan interpertasi sangat layak. Respon peserta didik kelas XI AKL di SMK Yapalis Krian dengan pelaksanaan uji coba terbatas menunjukkan interpertasi kelayakan sangat memahami. Hasil tersebut didapatkan melalui penyebaran angket maka bahan ajar berupa e-book ini efektif dan layak digunakan dalam proses pembelajaran. 


\section{DAFTAR PUSTAKa}

Andi, P. (2015). Panduan Kreatif Membuat Bahan Ajar Inovatif. Diva Press.

Arianti, F. (2021). Pengembangan Bahan Ajar untuk Meningkatkan Kemampuan Representasi Matematis Siswa melalui Model Pembelajaran Prepospec Berbantuan TIK pada materi Sistem Persamaan Linier. PRISMA, Prosiding Seminar Nasional Matematika, 4, 208-216. https://journal.unnes.ac.id/sju/index.php/prisma/article/view/45014

Astuti, R., \& Rahmawati, D. (2017). Pengembangan Bahan Ajar Akuntansi Untuk Meningkatkan Kompetensi Siswa Pada Mata Pelajaran Praktik Akuntansi Manual. Jurnal Pendidikan Akuntansi Indonesia, 15(1). https://doi.org/10.21831/jpai.v15i1.14808

BSNP. (2014). Instrumen Penilaian Buku Teks Pelajaran Tahun 2014. Badan Standar Nasional Pendidikan.

Dwi Saputra, M., Joyoatmojo, S., \& Kusuma Wardani, D. (2018). The Assessment of CriticalThinking-Skill Tests for Accounting Students of Vocational High Schools. International Journal of Educational Research Review, 3(4), 85-96. https://doi.org/10.24331/ijere.453860

Efendhi, E. S., \& Susilowibowo, J. (2013). Pengembangan Bahan Ajar Buku Berjendela sebagai Pendukung Implementasi Pembelajaran Berbasis Scientific Approach pada Materi Jurnal Khusus. Jurnal Pendidikan Akuntansi (JPAK), 2(2), 1-6. https:/jurnalmahasiswa.unesa.ac.id/index.php/jpak/article/viewFile/9434/9330

Fadillah. (2014). Implementasi Kurikulum 2013 Dalam Pembelajaran SD/MTS, dan SMA/MA. Ar-Ruzz Media.

Fitriani, I. dan S. R. (2019). Pengembangan E-BOOK Berbasis Android dengan Pendekatan Saintifik Pada mata pelajaran Administrasi Pajak Kelas XII Akuntansi DI SMK Negeri 2 Buduran. 1-22.

Hikmawati, H., Kosim, K., \& Sutrio, S. (2019). Desain Perangkat Pembelajaran Fisika Dengan Metode Real Experiments Dan Virtual Experiments. ORBITA: Jurnal Kajian, Inovasi Dan Aplikasi Pendidikan Fisika, 5(2), 88. https://doi.org/10.31764/orbita.v5i2.1303

Kirana, R \& Susilowibowo, J. (2020). Jurnal Pendidikan Akuntansi Indonesia, Vol. 18, No. 1, Tahun 2020. 18(1), 48-65.

Micheal F, Suarez, S.J., \& Wooudhuyusen, H. R. (2013). The Book a Global History. Oxford University Press.

Nurfita, R., \& Susanti. (2018). Pengembangan Bahan Ajar Akuntansi Keuangan Berbasis Kontekstual Pada Materi Rekonsiliasi Bank Kelas XI Akuntansi SMK Negeri Di Surabaya. Jurnal Pendidikan Akuntansi (JPAK), 6(3), 308-314. jurnalmahasiswa.unesa.ac.id/index.php/jpak/article/view/26129

Octaviana, R. A. (2017). Pengembangan Buku Ajar Akuntansi Kas Berbasis Scientific Approach Pada Mata Pelajaran Akuntansi Keuangan Kelas XI Di SMK Se Surabaya. Jurnal Pendidikan Akuntansi, 1-6.

Pratiwi, A. Z. R. (2019). Pengembangan Bahan Ajar E-Book Interaktif Pendekatan Kurikulum 2013 Mata Pelajaran Praktikum Akuntansi Lembaga/Instansi Pemerintah Kelas XI AKL SMK Negeri 1 Lamongan. Jurnal Pendidikan Akuntansi, 07(02), 145-151.

Prayogi, S., Yuanita, L., \& Wasis. (2018). Critical-Inquiry-Based-Learning: Model of Learning to Promote Critical Thinking Ability of Pre-service Teachers. Journal of Physics: Conference Series, 947(1). https://doi.org/10.1088/1742-6596/947/1/012013

Putra, R. W. Y., \& Pamungkas, A. S. (2019). PENGEMBANGAN BAHAN AJAR GAMIFIKASI MATEMATIKA SISWA MTs. Jurnal Penelitian Dan Pembelajaran Matematika, 12(1). https://doi.org/10.30870/jppm.v12i1.4865

Ramdhani, M. R., Usodo, B., \& Subanti, S. (2017). Discovery Learning with Scientific Approach on Geometry. Journal of Physics: Conference Series, 895(1). https://doi.org/10.1088/17426596/895/1/012033 
Restiyowati, I., \& Sanjaya, I Gusti, M. (2012). Keywords: learning resources, interactive ebook Abstrak: Unesa Journal of Chemical Education, 1(1), 130-135.

Riduwan. (2016). Skala Pengukuran Variabel-Variabel Penelitian. Alfabeta.

Ruddamayanti, R. (2019). Pemanfaatan Buku Digital Dalam Meningkatkan Minat Baca. Prosiding Seminar Nasional Pendidikan Program Pascasarjana Universitas PGRI Palembaang., 2, 364-370.

Saputri, A. E., \& Susilowibowo, J. (2020). Pengembangan Bahan Ajar E-Book pada Mata Pelajaran Praktikum Akuntansi Perusahaan Manufaktur. Jurnal Penelitian Pendidikan, 20, 154-162.

Sari, E. N., \& Zamroni, Z. (2019). The impact of independent learning on students' accounting learning outcomes at vocational high school. Jurnal Pendidikan Vokasi, 9(2), 141-150. https://doi.org/10.21831/jpv.v9i2.24776

Setiyoningrum, D. A., \& Susilowibowo, J. (2019). Pengembangan Buku Ajar Pada Mata Pelajaran Akuntansi Dasar Materi Penyusunan Laporan Keuangan Perusahaan Manufaktur Berbasis Pendekatan Saintifik Kelas X AKL Di SMK Negeri 10 Surabaya. Jurnal Pendidikan Akuntansi (JPAK), 7(2), 152-159.

Suarman, S., Hendripides, H., \& Hikmah, N. (2018). Development of Innovative Teaching Materials through Scientific Approach. Journal of Educational Sciences, 2(2), 14. https://doi.org/10.31258/jes.2.2.p.14-22

Sumiadi, R. D. S. D. J. J. (2015). Pengembangan Perangkat Pembelajaran Berbasis pendekatan saintifik Model Guide Discovery dan Efektifitasnya Terhadap Kemampuan Berpikir Kreatif Siswa SMA Negeri 1 Bayan. $X(1), 29-32$.

Tania, L. (2017). Pengembangan Bahan Ajar E-Modul Sebagai Pendukung Pembelajaran Kurikulum 2013 Pada Materi Ayat Jurnal Penyesuaian Perusahaan Jasa Siswa Kelas X Akuntansi Smk Negeri 1 Surabaya. Jurnal Pendidikan Akuntansi (JPAK), 5(2), 1-9.

Wahyuni, S. (2015). Pengembangan Petunjuk Praktikum Ipa Untuk Meningkatkan Kemampuan Berpikir Kritis Siswa Smp. Jurnal Pengajaran Matematika Dan Ilmu Pengetahuan Alam, 6(1), 196. https://doi.org/10.18269/jpmipa.v20i2.585

Zaim, M. (2017). Implementing Scientific Approach to Teach English at Senior High School in Indonesia. Asian Social Science, 13(2), 33. https://doi.org/10.5539/ass.v13n2p33 